\title{
The Dutch Experience in Percutaneous Transluminal Angioplasty of Narrowed Saphenous Veins Used for Aortocoronary Arterial Bypass
}

\author{
H. W. Thijs Plokker, MD, PhD, B. Hannie Meester, MD, and Patrick W. Serruys, MD, PhD
}

\begin{abstract}
Of 19,994 percutaneous transluminal coronary angioplasty procedures performed in The Netherlands between April 1980 and January 1989, the longterm follow-up of $\mathbf{4 5 4}$ patients who underwent angioplasty of $\geq 1$ saphenous vein bypass graft was reviewed. In $46 \%$ of patients single graft angioplasty was attempted, and in $54 \%$ of patients sequential graft angioplasty was attempted. The clinical primary success rate was $\mathbf{9 0 \%}$. In-hospital mortality was $0.7 \%, 2.8 \%$ of patients sustained a procedural myocardial infarction, and $1.3 \%$ of patients underwent emergency bypass surgery. After a follow-up period of 5 years, $74 \%$ of patients were alive, and $26 \%$ were alive and event-free (no myocardial infarction, no repeat bypass surgery or repeat angioplasty). In patients in whom the initial angioplasty attempt was unsuccessful, only $3 \%$ were event-free at 5 years, versus $27 \%$ of successfully dilated patients. The time interval between the angioplasty attempt and previous surgery was a significant predictor for 5-year event-free survival. The event-free survival rates for patients who had bypass surgery 1 year before, between 1 and 5 years, and 5 years before angioplasty, were 45, 25 and $19 \%$, respectively. Less than one-third of patients with previous bypass surgery who had angioplasty of the graft remained event-free after 5 years. In patients needing angioplasty within 1 year after bypass surgery, better long-term results were achieved.
\end{abstract}

(Am J Cardiol 1991;67:361-366)

From the Interuniversity Cardiology Institute of The Netherlands (ICIN), Utrecht; Thoraxcenter, Erasmus University, Rotterdam; and the Department of Cardiology, St. Antonius Hospital, Nieuwegein, The Netherlands. Manuscript received June 1, 1990; revised manuscript received and accepted October 5, 1990.

Address for reprints: Patrick W. Serruys, MD, PhD, Catheterization Laboratory, Thoraxcenter, Erasmus University, P.O. Box 1738, 3000 DR Rotterdam, The Netherlands.

See Appendix for participating centers and institutions.
R ecurrence of angina pectoris after aortocoronary bypass surgery in patients with coronary artery disease is either caused by progression of disease in the native coronary artery or by the development of new narrowings in $\geq 1$ bypass graft. Because of the increased morbidity and mortality of coronary reoperations, it is not surprising that percutaneous transluminal balloon angioplasty has been attempted in such patients to prevent a reoperation. It has been demonstrated ${ }^{1-9}$ that angioplasty can be successfully performed in patients with a hemodynamically significant stenosis in a venous coronary bypass graft. Little is known about the long-term outcome after angioplasty. 8,10 In this study, we evaluated the long-term clinical effects of balloon angioplasty in venous bypass grafts in all 454 patients who had undergone such a procedure in The Netherlands between April 1980 (when the first coronary angioplasty procedure was performed) and January 1989. During this time period, a total of 19,994 coronary angioplasty procedures were performed in the country, of which the 454 patients represent $2.7 \%$.

\section{METHODS}

Between April 1980 and January 1989, 454 patients underwent angioplasty of at least 1 stenosis of $>50 \%$ diameter in $\geq 1$ saphenous vein bypass graft. Two hundred and sixty-four of 454 patients $(58.1 \%)$ underwent an angioplasty either of the bypass graft and $\geq 1$ native vessel (38 patients, 14.4\%) or of the bypass graft alone (226 patients, $85.6 \%$ ). There were 368 men (81\%) and 86 women (19\%) aged 34 to 78 years (mean \pm standard deviation $60 \pm 8.4)$. The number of diseased vessels was known for 200 of the 454 patients (44.1\%). One-vessel disease was reported in 15 of 200 patients $(7.5 \%)$, 2vessel disease in 36 patients (18\%) and 3-vessel disease in 149 patients $(74.5 \%)$. In $46 \%$ of patients $\geq 1$ stenoses in $\geq 1$ single graft were dilated, and in $54 \%$ of patients $\geq 1$ stenoses in a sequential or jump graft were dilated. In the patients who underwent single graft angioplasty, dilatation was attempted in $69 \%$ in grafts to the left anterior descending artery, in $21 \%$ in grafts to the right coronary artery and in $10 \%$ in grafts to the circumflex artery. The interval between coronary artery bypass surgery and balloon dilatation (or "graft age") ranged from 6 months to 17 years (mean age $5.7 \pm 3.8$ years) (Figure 1).

Primary success was defined as a reduction of the diameter stenosis to $\leq 50 \%$, without the occurrence of 
an acute myocardial infarction, emergency bypass surgery or death, during the hospital stay of the patients. Acute myocardial infarction was defined as the occurrence of new $Q$ waves on the electrocardiogram $\geq 30 \mathrm{~ms}$ or an increase in creatine phosphokinase to $>3$ times normal. Aortocoronary bypass surgery was considered to be an emergency when the patient was immediately transfcrrcd from the cardiac catheterization laboratory to the operating room.

Follow-up data were first obtained by means of a letter to the Civil Registration Service to establish survival status. If the patients were alive, they were interviewed by telephone, written questionnaires or outpatient clinic visits. The following events were considered as clinical end points: death, acute myocardial infarction, reoperation and redilatation.

All data are presented as mean \pm 1 standard deviation. Life tables were actuarially calculated according to the Kaplan-Meier method. The generalized Wilcoxon test was performed to detect differences between the subgroups. A p value $<0.05$ was considered statistically significant.

\section{RESULTS}

The primary success rate was $90 \%$. In-hospital mortality was $0.7 \%$. In $2.8 \%$ of patients there was evidence of a procedural acute myocardial infarction. In $1.3 \%$ of patients emergency coronary artery bypass surgery was performed.

Actuarial survival for the entire group was $74 \%$ $( \pm 3.4 \%)$ at 5 years (Figure 2$)$ and $63 \%( \pm 8 \%)$ at 8 years. However, in patients with initial unsuccessful graft angioplasty, $58 \%$ were alive at 5 years versus $78 \%$ of patients in whom graft angioplasty was successful ( $p$ $<0.001$ ) (Figure 3).

After a follow-up period of 5 years, $58 \%$ of patients were alive and did not sustain a myocardial infarction. Thirty-four percent were alive, had no evidence of a myocardial infarction, and did not undergo repeat bypass surgery. After these 5 years $26 \%$ of patients
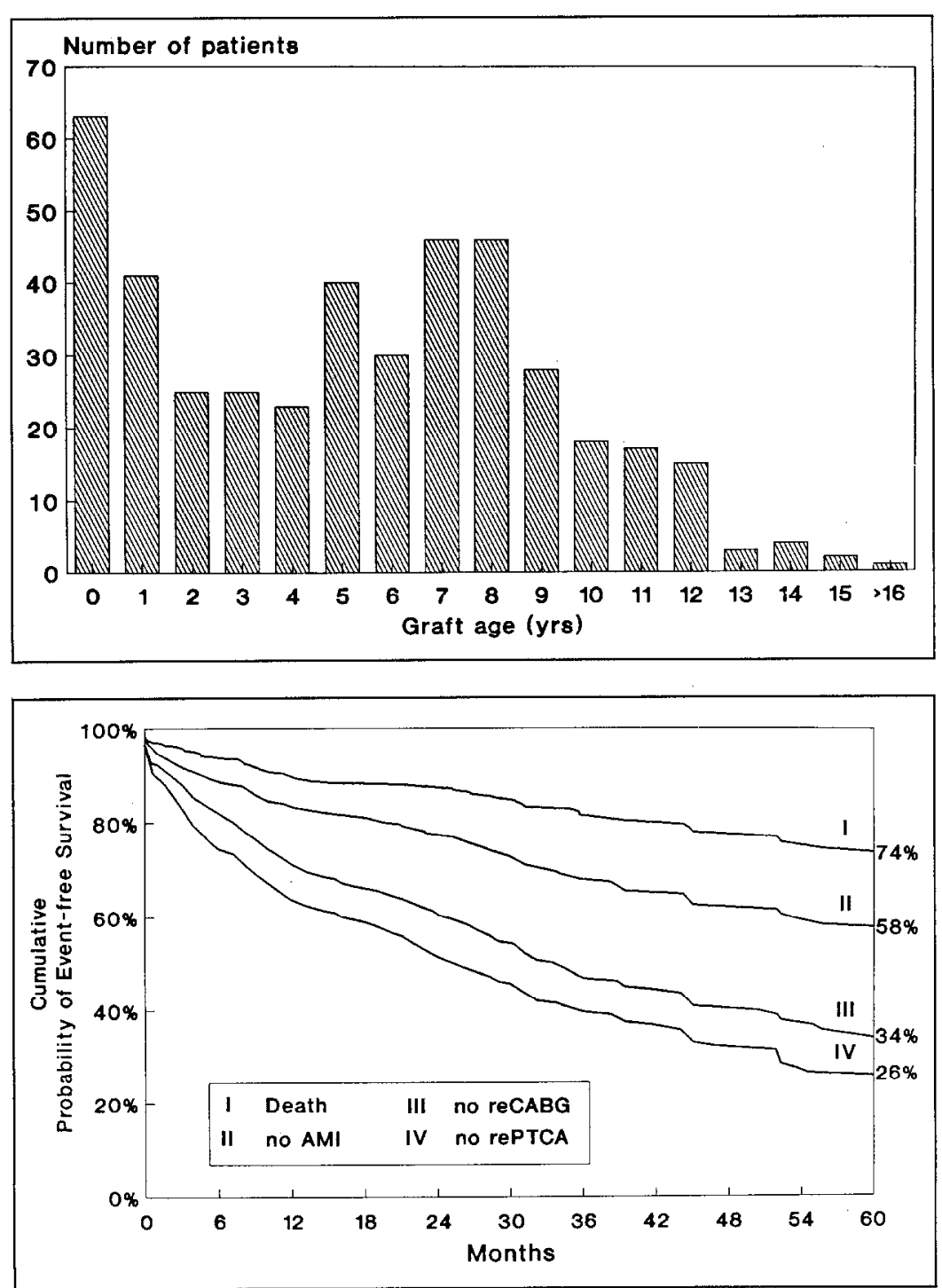

FIGURE 1. The time interval between graft angioplasty and previous surgery ("graftage") ranged from 6 months to 17 years (mean age $5.7 \pm 3.8$ years).
FIGURE 2. After the follow-up period of 5 years, the cumulative probability of survival without any cardiac event (death, myocardial infarction, repeat bypass surgery and repeat angioplasty) was $26 \%$ $( \pm 3.3 \%)$ for all 454 patients. AMI = acute myocardial infarction; reCABG = repeat coronary artery bypass grafting; rePTCA = repeat percutaneous transluminal coronary angioplasty. 
$( \pm 3.3 \%)$ were alive and event-free. When only death, myocardial infarction and reoperation were considered as clinical end points, $34 \%$ of patients were alive and event-free after 5 years (Figure 2).

In patients in whom the initial graft angioplasty attempt was unsuccessful, only $3 \%$ were event-free at 5 years, versus $27 \%$ event-free patients in whom initial graft angioplasty was successful ( $p<0.0001$ ) (Figurc 4). When grouped by graft age (intervals between bypass surgery and angioplasty $<1$ year, between 1 and 5 years, and $\geq 5$ years), there were statistically significant differences in 5-year event-free survival rates, namely $45 \%$ for patients who underwent angioplasty within 1 year after bypass surgery, in contrast to 25 and $19 \%$ for patients with grafts that had been implanted between 1 and 5 years, and $>5$ years before angioplasty, respectively $(\mathrm{p}<0.005)$ (Figure 5).

\section{DISCUSSION}

Between April 1980 and January 1989, 19,994 angioplasty procedures were performed in The Netherlands.
In this large collected angioplasty experience, only $2.7 \%$ of procedures included vein graft dilatation. Many contemporary series have a larger number of patients with graft dilatation. However, our reported incidence of $2.7 \%$ is a cumulative number and does not reflect the current percentage of patients undergoing graft angioplasty in The Netherlands, which was $4.1 \%$ in 1988 . In 1988 the percentage of patients with previous bypass surgery undergoing angioplasty of the graft or $\geq 1$ more native vessel, or both, was $10.3 \%$.

Furthermore, between 1980 and 1989 there has been a progressive recruitment of centers. The number of catheterization laboratories performing angioplasty in the country increased from 5 to 12 . In addition, the expansion of the indication of graft angioplasty has been a slowly evolving phenomenon, which is also shown by the high incidence of bypass operations in The Netherlands.

Recurrence of angina after coronary artery bypass grafting remains a major clinical problem. Failure of aortocoronary saphcnous vcin bypass grafts is generally the result of either vein graft stenosis or progressive ath-
FIGURE 3. The cumulative probability of 5-year survival grouped by success. In patients in whom graft angioplasty had been unsuccessful, the probability of survival was significantly lower $(\mathbf{5 8} \%)$ than in those in whom graft angioplasty had been successful $(\mathbf{7 8} \%)(p<0.001)$.
FIGURE 4. The cumulative probability of 5-year event-free survival grouped by success. In patients in whom the initial graft angioplasty attempt had been unsuccessful, the chance of remaining event-free for the first 5 years after the procedure was as low as $3 \%$, compared with $27 \%$ for those in whom graft angioplasty had been successful (p $<0.0001)$.
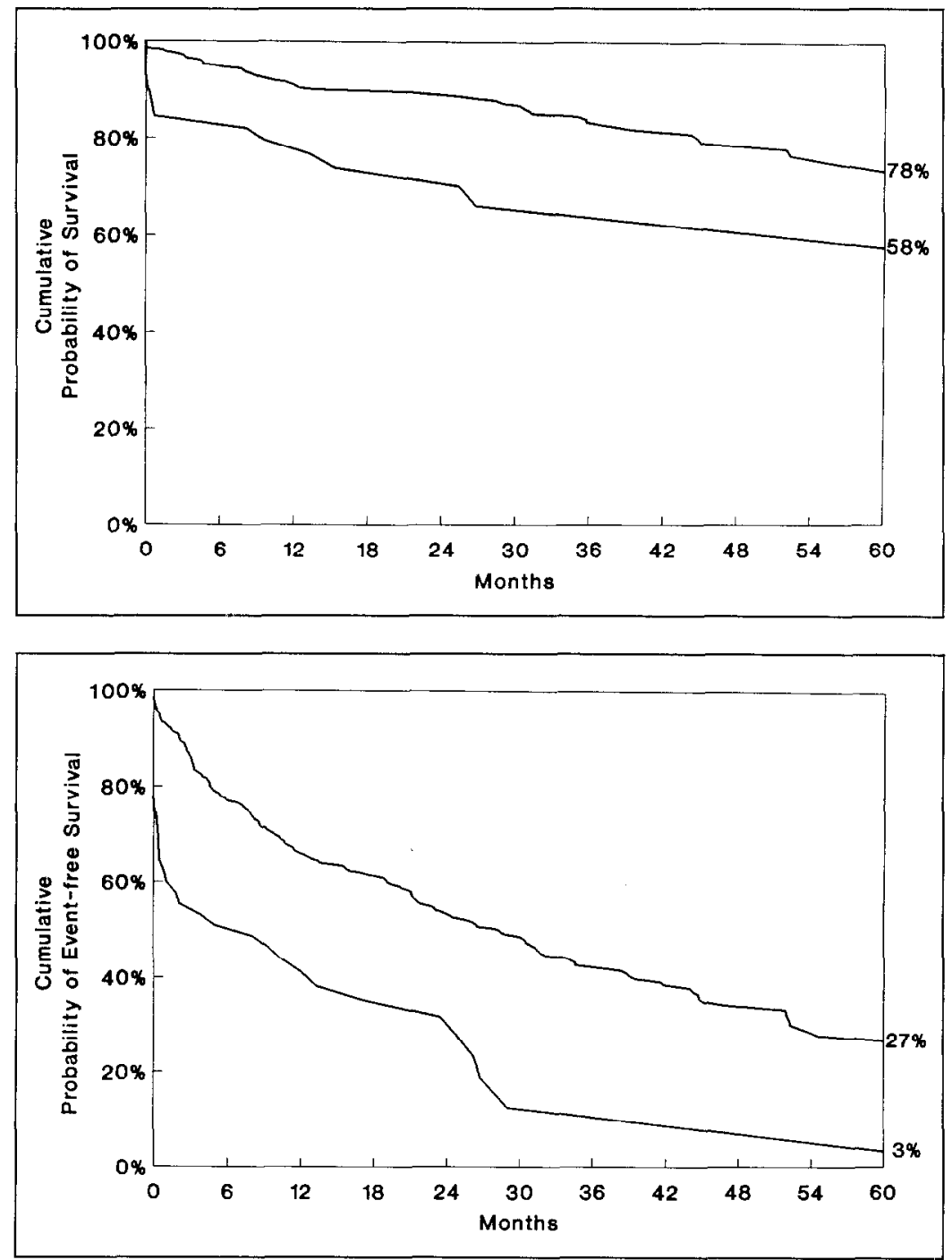


\begin{tabular}{|c|c|c|c|}
\hline Ycar & Authors & $\begin{array}{l}\text { No. of } \\
\text { SVG PTCAs }\end{array}$ & $\begin{array}{l}\text { No. of } \\
\text { Successes } \\
(\%)\end{array}$ \\
\hline 1981 & Ford et al ${ }^{24}$ & 9 & 89 \\
\hline 1983 & Douglas et al ${ }^{1}$ & 62 & 94 \\
\hline \multirow[t]{3}{*}{1984} & Block et al ${ }^{2}$ & 40 & 78 \\
\hline & Dorros et $\mathrm{a}^{8}$ & 33 & 79 \\
\hline & El Gamal et al ${ }^{29}$ & 44 & 93 \\
\hline \multirow[t]{3}{*}{1985} & Corbelli et $a^{3}$ & 47 & 91 \\
\hline & Marquis et al ${ }^{4}$ & 24 & 79 \\
\hline & Slysh et $a 1^{5}$ & 6 & 100 \\
\hline 1986 & Reeder et $\left.\mathrm{a}\right|^{6}$ & 19 & 84 \\
\hline \multirow[t]{3}{*}{1987} & Cote et al ${ }^{7}$ & 88 & 86 \\
\hline & Ernst et al ${ }^{10}$ & 33 & 97 \\
\hline & Pop et $\mathrm{al}^{30}$ & 49 & 74 \\
\hline \multirow[t]{3}{*}{1988} & Dorros et al ${ }^{12}$ & 53 & 83 \\
\hline & Pinkcrton et al ${ }^{9}$ & 100 & 93 \\
\hline & \multicolumn{2}{|c|}{ Overail 607} & 87 \\
\hline
\end{tabular}

erosclerotic narrowing of distal native coronary arteries. Symptoms of myocardial ischemia will recur or progress in about $5 \%$ of patients per year. ${ }^{11,12}$ Early graft narrowing occurs in up to $10 \%$ of grafts within 1 to 2 weeks after the operation and 15 to $20 \%$ by 1 year. ${ }^{13-15}$ After 5 years, up to $25 \%$ of grafts are occluded, whereas $52 \%$ may show stenoses of $>70 \% .{ }^{15}$ Stenosis within the first month is almost always due to thrombosis and is generally related to technical factors such as anastomotic narrowing, operative trauma to the vein graft and inadequate distal runoff. ${ }^{12}$ It has been demonstrated that between 1 month and 1 year postoperatively, intimal fibromuscular proliferation is the most prevalent form of obstruction. Postoperatively, beyond 1 year and particularly after 3 years, atherosclerosis becomes an important cause of vein graft stenosis and may coexist with fibromuscular proliferation.

Plaques in vein grafts resemble those in native coronary arteries and are generally soft and friable rather than densely fibrotic or calcific. Furthermore, because vein grafts tend to be larger than the native coronary arteries to which they are anastomosed, and because vein graft atherosclerosis often occurs in aneurysmally dilated segments, the plaques are generally quite large relative to those in native coronary arteries. Accordingly, atherosclerotic plaques in vein grafts seem particularly vulnerable to disruption and to embolization of relatively large fragments.

Although coronary artery bypass surgery using internal mammary artery grafts gives much better longterm graft patency rates, ${ }^{7-9,16}$ vein grafts will continue to be utilized in a majority of surgical candidates with multivessel coronary artery disease, because not all vessels can be bypassed using internal mammary conduits.

Reoperation is technically more complicated to perform and is generally associated with a higher morbidity and mortality than a primary operation, and achieves symptomatic relief in only 60 to $70 \%$ of paticnts, compared with the 80 to $90 \%$ success rate after primary operations. The perioperative myocardial infarction rate varies among surgical groups from 2.0 to $11.5 \%$. The mortality rate after repeat bypass surgery varies from 1.2 to $12.5 \%$, and the incidence of reoperation for bleeding ranges from 3.6 to $10.2 \% .{ }^{17}{ }^{23}$

Angioplasty of a saphenous vein bypass graft was first performed in 1978 by Ford. ${ }^{24}$ Since then a number of publications have shown the feasibility of this technique, with an overall success rate of $87 \%$ (Table I). Almost the same success rate was seen in our combined Dutch series. These rather high success rates probably reflect careful patient selection. Long midgraft lesions with highly irregular borders were usually avoided because of the risk of distal embolization from detached material within the grafts, but our angiographic data are insufficient to further detail the angiographic appearance of the lesions before percutaneous transluminal coronary angioplasty.

After a follow-up period of 5 years, $74 \%$ of 454 patients were alive, and only $26 \%$ of patients were alive and event-free. The number of diseased vessels was

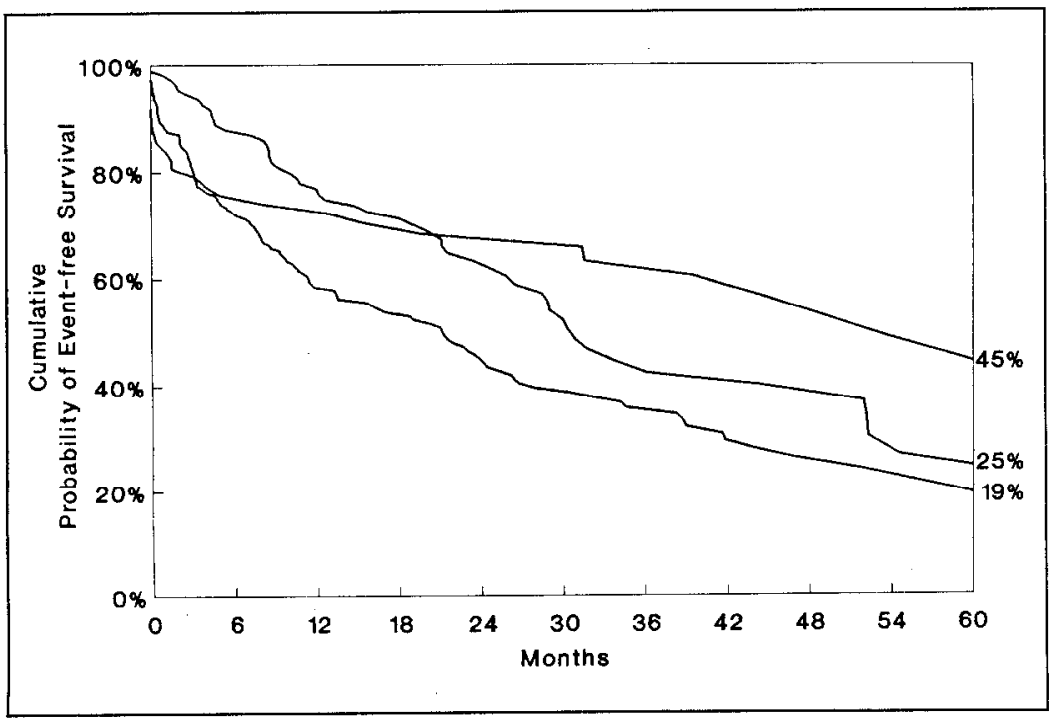

FIGURE 5. The cumulative probability of survival at 5 years grouped by graftage (intervals between coronary artery bypass grafting and angioplasty $<1$ year, between 1 and 5 years, and $\geq 5$ years). The differences in 5-year event-free survival rates were statistically significant: $45 \%$ for patients who underwent angioplasty within 1 year after surgery, compared with 25 and $19 \%$ for patients with grafts that had been implanted between 1 and 5 years, and at $\geq 5$ years before angioplasty ( $p$ $<0.005$ ). 
known for $44.1 \%$ of patients, so we could not ascertain the presence of multivessel disease as a factor leading to late events and reinterventions in the follow-up of these patients. Since, in this survey type of investigation, the reason for late events or repeat angioplasty or repeat bypass surgery is not available, it is difficult to speculate on the physiopathologic mechanism responsible for these follow-up events. We can not be certain if graft restenosis plays a major role in the high incidence of late events.

However, the interval between coronary artery bypass surgery and angioplasty was known in all our patients (Figure 1). There were statistically significant ( $\mathrm{p}$ $<0.05$ ) differences in event-free survival rates after a follow-up period of 5 years among patients who underwent bypass surgery within 1 year before angioplasty, between 1 and 5 years, and $>5$ years before angioplasty. Event-free survival was reported in 45,25 , and $19 \%$ of patients, respectively. This finding is in agreement with previously published data $1-3,7-9,12$ that suggest that anastomotic lesions respond better to angioplasty than lesions that occur later (midgraft). The manner in which balloon angioplasty relieves obstructions in vein grafts appears to be similar to that described for native coronary arteries and is characterized primarily by intimal tears and plaque disruption. Within the first postoperative month, balloon angioplasty may be beneficial to relieve stenoses, particularly at distal anastomosis sites. Angioplasty of aortocoronary saphenous vein bypass grafts $>1$ year of age can be performed with the realization that involvement by friable atherosclerosis is likely and that atheroembolization represents a risk. ${ }^{25,26}$

Eventually, the higher risk of reoperation will make the use of less aggressive forms of therapy more attractive. Angioplasty of the venous conduits, of the native vessels themselves and alternative forms of nonsurgical revascularization such as atherectomy, stenting and laser (balloon) angioplasty may obviate repeat bypass surgery in some patients. ${ }^{27,28}$ However, within the limits of our study, we have not been able to look at the results of angioplasty of native coronary arteries in patients who again become symptomatic after venous bypass graft procedures. From published reports it seems that this technique also has its limitations. ${ }^{1,3,10,12}$

Our data demonstrate that $74 \%$ of patients who undergo angioplasty of a stenosis in a venous graft survive 5 years after the angioplasty procedure, and that only $26 \%$ remain free of any major event. However, in patients needing angioplasty within 1 year after bypass surgery, better long-term results can be achieved. Finally, angioplasty of a venous graft stenosis may be an alternative to reoperation in some patients with previous coronary artery bypass surgery.

It is the inherent limitation of this type of epidemiologic historical survey, that, although it provides the clinical investigator with large numbers, the nonprospective nature of this investigation does not permit one to identify the factors that may improve patient selection.

Acknowledgment: We thank Ed van de Berge (CADANS/ICIN) and Piet Jonkers (Thoraxcenter) for their great help in data acquisition and data processing.

\section{REFERENCES}

1. Douglas JS, Gruntzig AR, King SB III, Hollman J, Ischinger T, Meier B, Craver JM, Jones EL, Waller JL, Bone DK, Guyton R. Percutaneous transluminal coronary angioplasty in paticnts with prior coronary bypass surgery. $J \mathrm{Am}$ Coll Cardiol 1983;2:745-754.

2. Block PC, Cowley MJ, Kaltenbach M, Kent KM, Simpson J. Percutaneous angioplasty of stenoses of bypass grafts or of bypass graft anastomotic sites. $\mathrm{Am} . I$ Cardiol 1984;53:666-668

3. Corbelli J, Franco I, Hollman J, Simpfendorfer C, Galan K. Percutaneous transluminal coronary angioplasty after previous coronary artery bypass surgery. Am J Cardiol 1985:56:398-403.

4. Marquis JF, Schwartz L, Brown R, Matushinsky E, Mickleborough L, Aldridge $H$, Henderson $M$. Percutaneous transluminal angioplasty of coronary saphenous vein bypass grafts. Can J Surg 1985;28:335-337.

5. Slysh S, Goldberg S, Dervan JP, Zalewski A. Unstable angina and evolving myocardial infarction following coronary bypass surgery: pathogenesis and treat* ment with interventional catheterization. Am Heart $J$ 1985;109:744-752.

6. Reeder GS, Bresnahan JF, Holmes DR, Mock MB, Orszulak TA, Smith HC, Vlietstra RE. Angioplasty for aortocoronary bypass graft stenosis. Mayo Clin Proc 1986;61:14-19.

7. Cote G, Myler RK, Stertzer SH, Clark DA, Fishman-Rosen J, Murphy M, Shaw RE. Percutaneous transluminal angioplasty of stenotic coronary artery bypass grafts: 5 years' experience. $J$ Am Coll Cardiol 1987;9:8-17.

8. Dorros G, Lewin RF, Mathiak LM, Johnson WD, Brenowitz J, Schmahl 'T' Tector A. Percutaneous transluminal coronary angioplasty in patients with two or more previous coronary artery bypass grafting operations. Am J Cardiol 1988;61:1243-1247.

9. Pinkerton CA, Slack JD, Orr CM, Vantassel JW, Smith ML. Percutaneous transluminal angioplasty in patients with prior myocardial revascularization surgery. Am J Cardiol 1988;61:15G-22G

10. Ernst JMPG, van der Feltz TA, Ascoop CAPL, Bal ET, Vermeulen FEE, Knaepen PJ, van Bogerijen L, van den Berg EJM, Plokker HWM. Percutaneous transluminal coronary angioplasty in patients with prior coronary artery bypass grafting. J Thorac Cardiovasc Surg 1987;93:268-275.

11. Laird-Meeter K, Penn OCKM, Haalebos MMP, van Domburg R, Lubsen J, Bos E, Hugenholtz PG. Survival in 1041 patients with consecutive aorto-coronary bypass opcrations. Eur Heart $J$ 1984;5:35-42.

12. Dorros G, Johnson WD, Tector AJ, Schmahl TM, Kalush SL, Janke L. Percutaneous transluminal coronary angioplasty in patients with prior coronary artery bypass grafting. $J$ Thorac Cardiovasc Surg 1984;87:17-26.

13. Campeau L, Crochet D, Lesperance J, Bourassa MG, Grondin CM. Postoperative changes in aortocoronary saphenous vein grafts revisited: angiographic studies at two weeks and at one year in two series of consecutive patients. Circulation 1975;52:369-377.

14. Pantely GA, Goodnight SH, Rahimtoola SH, Harlan BJ, DeMots $H$, Calvin L, Rosch J. Failure of antiplatelet and anticoagulant therapy to improve patency of grafts after coronary-artery bypass: a controlled, randumized study. $N$ Engl $J$ Med 1979;301:962-966

15. Brown BG, Cukingnan RA, DeRouen T, Goede LV, Wong M, Fee HJ, Roth JA, Carey IS. Improved graft patency in patients treated with platelet-inhibiting therapy after coronary bypass surgery. Circulation 1985;72:138-146.

16. Kereiakes DJ, George B, Stertzer SH, Myler RK. Percutaneous coronary angioplasty of left internal mammary artery grafts. Am J Cardiol 1985;55:12151216

17. Keon WJ, Bedard P, Akyurekli Y, Brais M. Experience with reoperation following coronary bypass grafting. Can J Surg 1977;20:142-146.

18. Culliford AT, Girdwood RW, Isom OW, Kraus KR, Spencer FC. Angina following myocardial revascularization. J Thorac Cardiovasc Surg 1979;77:889895.

19. Reul GJ, Cooley DA, Ott DA, Coelho A, Chapa L, Eterovic I. Reoperation for recurrent coronary artery disease. Arch Surg 1979;114:1269-1275.

20. Vouhe $P$, Grondin CM. Reoperation for coronary graft failure: clinical and angiographic results in 43 patients. Ann Thorac Surg 1979;27:328-334.

21. Loop FD, Cosgrove DM, Kramer JR, Lytle BW, Taylor PC, Golding LAR, Groves LK. Late clinical and arteriographic results in 500 coronary artery reoperations. $J$ Thorac Cardiovasc Surg 1981;81:675-685.

22. Lylle BW, Loop FD, Cosgrove DM, Taylor PC, Goormastic M, Peper W, Gill CC, Golding LAR, Stewart RW. Fifteen hundred coronary reoperations. Results and determinants of early and late survival. $J$ Thorac Cardiovasc Surg 1987.93.847-850.

23. Laird-Meeter K, van Domburg R, van den Brand MJ, Lubsen J, Bos E, Hugenholtz $\mathbf{P G}$. Incidence, risk and outcome of reintervention after aortocoronary bypass surgery. Br Heart $J$ 1987;57:427-435.

24. Ford WB, Wholey MH, Zikria EA, Somadani SR, Sullivan ME. Percutaneous transluminal dilation of aortocoronary saphenous vein bypass grafts. Chest 1981;79:529-535

25. Saber RS, Edwards WD, Holmes DR, Vlietstra RE, Reeder GS. Balloon angioplasty of aortocoronary saphenous vein bypass grafts: a histopathologic 
study of six grafts from five patients, with emphasis on restenosis and embolic complications. J Am Coll Cardiol 1988;12:1501-1509.

26. Waller BF, Rothbaum DA, Gorfinkel HJ, Ulbright TM, Linnemeier TJ, Berger SM. Morphologic observations a [lter percutaneous transluminal balloon angioplasty of early and late aortocoronary saphenous vein bypass grafts. $J \mathrm{Am}$ Coll Cardiol 1984:4:784-792.

27. Sigward U, Puel J, Mirkowitch V, Joffre F, Kappenberger L. Intravascular stents to prevent occlusion and restenosis after transluminal angioplasty. $N$ Engl $J$ Med 1987;316:701-706.

28. Litvack F, Grundfest WS, Goldenberg T, Laudenslager J, Forrester JS. Percutaneous excimer laser angioplasty of aortocoronary saphenous vein grafts. $J$ Am Coll Cardiol 1989;14:803-808.

29. El Gamal MIH, Bonnier H, Michels R, Heyman J, Stassen E. Percutaneous transluminal angioplasty of stenosed aortocoronary bypass grafts. $\mathrm{Br}$ Heart $\mathrm{J}$ 1984:52:617-620.

30. Pop G, van den Brand M, Essed N, de Feyter PJ, Suryapranata H, Serruys PW. Bypass graft occlusion: repeat bypass surgery or balloon dilatation in the graft? (Dutch publication) Hart Bulletin 1987;18:123-126.

\section{APPENDIX}

Participating centers and institutions: Amsterdam, University Hospital: G. K. David, MD, PhD, G. Hoedemaker, MD, J. J. Koolen, MD, PhD; Eindhoven, Catharina Hospital:
J. J. R. M. Bonnier, MD, M. F. El Deeb, MD, M. I. H. El Gamal, MD, H. R. Michels, MD, T. H. Relik, MD; Groningen, University Hospital: R. B. van Dijk, MD, P. den Heijer, MD, A. J. G. M. Krijns, MD; Leiden, University Hospital: A. L. M. Bakx, MD, H. A. Bosker, MD, B. Buis, MD, PhD, L. P. D. van der Linden, MD, M. I. Sedney, MD, PhD; Maastricht, University Hospital: F. W. H. M. Bär, MD, G. V. A. van Ommen, MD, J. B. R. M. de Swart, MD; Nieuwegein, St Antonius Hospital: E. T. Bal, MD, J. M. P. G. Ernst, MD, PhD, E. G. Mast, MD, H. W. M. Plokker, MD, PhD; Nijmegen, University Hospital: W. R. M. Aengevaeren, MD, J. H. Fast, MD, PhD, K. van Leeuwen, MD, PhD, N. H. J. Pijls, MD; Rotterdam, Thoraxcenter: M. van den Brand, MD, P. J. de Feyter, MD, PhD, P. Jonkers, G. J. Laarman, MD, B. J. Meester, MD, P. W. Serruys, MD, PhD, H. Suryapranata, MD, PhD; Utrecht, Cardiological Data Network System (CADANS): E. van de Berge, G. T. Meester, MD, PhD, O. E. Sartorius, MD; Utrecht, University Hospital: J. F. G. Bronzwaer, MD, H. W. J. Meijburg, MD, P. W. Westerhof, MD, PhD; Zwolle, Hospital De Weezenlanden: M. J. de Boer, MD, J. C. A. Hoorntje, MD, PhD, F. Zijlstra, MD, PhD 